\title{
Correction to: Reversibility of motor dysfunction in the rat model of NGLY1 deficiency
}

Makoto Asahina ${ }^{1,3}$, Reiko Fujinawa ${ }^{2,3}$, Hiroto Hirayama ${ }^{2,3}$, Ryuichi Tozawa ${ }^{1,3}$, Yasushi Kajii and Tadashi Suzuki ${ }^{2,3^{*}}$

\section{Correction to: Mol Brain (2021) 14:91} https://doi.org/10.1186/s13041-021-00806-6 Following publication of the original article [1], the authors would like to correct 2 errors in the "Methods" section.

The first sentence in the "Preparation of cytosolic fraction and enrichment of NGLY1" subsection originally read:

For preparation of lysate, $50 \mathrm{mg}$ of rat brain was sliced and resuspended in $500 \mu \mathrm{l}$ NGLY1 buffer (5 mM Tris-HCl; pH 7.5), $250 \mathrm{mM}$ glycerol, $1 \mathrm{mM}$ Pefabloc ${ }^{\text {TM }}$ SC (Sigma-Aldrich; 11429868001), and $1 \times$ cOmplete $^{\mathrm{TM}}$ protease inhibitor cocktail (SigmaAldrich; 11836145001).

The sentence should read (the change has been highlighted in bold typeface):

For preparation of lysate, $50 \mathrm{mg}$ of rat brain was sliced and resuspended in $500 \mu$ l NGLY1 buffer (100 $\mathrm{mM}$ Tris- $\mathrm{HCl} ; \mathrm{pH}$ 7.5, $250 \mathrm{mM}$ sucrose, $1 \mathrm{mM}$ Pefabloc ${ }^{\mathrm{TM}} \mathrm{SC}$ (Sigma-Aldrich; 11429868001), and $1 \times$ cOmplete $^{\text {TM }}$ protease inhibitor cocktail (SigmaAldrich; 11836145001)).

The second sentence in the "Activity assay of the enriched NGLY1 fraction" section originally read:

The original article can be found online at https://doi.org/10.1186/s13041 021-00806-6.

${ }^{*}$ Correspondence: tsuzuki_gm@riken.jp

${ }^{2}$ Glycometabolic Biochemistry Laboratory, RIKEN Cluster for Pioneering

Research, RIKEN, 2-1 Hirosawa, Wako, Saitama 351-0198, Japan

Full list of author information is available at the end of the article
Briefly, the reaction mixture containing $25 \mu \mathrm{l}$ of the NGLY1 fraction in a total volume of $30 \mu \mathrm{l}$ of $10 \mathrm{mM}$ Tris- $\mathrm{HCl}$ (pH 7.5), $50 \mathrm{mM}$ sucrose, $1 \mathrm{mM}$ DTT, $1 \mathrm{mM}$ Pefabloc $^{\text {TM }}$ SC, and $1 \times$ cOmplete $^{\text {TM }}$ protease inhibitor cocktail (EDTA-free) together with 53 pmol of BODIPY- asialoglycopeptide (BODIPY-ASGP) was incubated at $25^{\circ} \mathrm{C}$ for $6 \mathrm{~h}$.

The second sentence should read (the change has been highlighted in bold typeface):

Briefly, the reaction mixture containing $25 \mu \mathrm{l}$ of the NGLY1 fraction in a total volume of $30 \mu \mathrm{l}$ containing $1 \mathrm{mM}$ DTT, $1 \mathrm{mM}$ Pefabloc ${ }^{\mathrm{TM}} \mathrm{SC}$, and $1 \times$ cOmplete $^{\mathrm{TM}}$ protease inhibitor cocktail (EDTA-free) together with 53 pmol of BODIPY-asialoglycopeptide (BODIPYASGP) was incubated at $25^{\circ} \mathrm{C}$ for $6 \mathrm{~h}$.

These errors do not affect any of the conclusions presented in the article. The original article [1] has been corrected. original author(s) and the source, provide a link to the Creative Commons licence, and indicate if changes were made. The images or other third party material in this article are included in the article's Creative Commons licence, unless indicated otherwise in a credit line to the material. If material is not included in the article's Creative Commons licence and your intended use is not permitted by statutory regulation or exceeds the permitted use, you will need to obtain permission directly from the copyright holder. To view a copy of this licence, visit http://creativecommons.org/licenses/by/4.0/. The Creative Commons Public Domain Dedication waiver (http://creativeco mmons.org/publicdomain/zero/1.0/) applies to the data made available in this article, unless otherwise stated in a credit line to the data. 


\section{Author details}

TT-CiRA Discovery, Takeda Pharmaceutical Company Ltd., Fujisawa, Kanagawa 2518555, Japan. ${ }^{2}$ Glycometabolic Biochemistry Laboratory, RIKEN Cluster for Pioneering Research, RIKEN, 2-1 Hirosawa, Wako, Saitama 351-0198, Japan.

${ }^{3}$ Takeda-CiRA Joint Program (T-CiRA), Fujisawa, Kanagawa 2518555, Japan.

Published online: 16 August 2021

\section{Reference}

1. Asahina M, Fujinawa R, Hirayama H, Tozawa R, Kajii Y, Suzuki T. Reversibility of motor dysfunction in the rat model of NGLY1 deficiency. Mol Brain. 2021;14:91. https://doi.org/10.1186/s13041-021-00806-6.

\section{Publisher's Note}

Springer Nature remains neutral with regard to jurisdictional claims in published maps and institutional affiliations.
Ready to submit your research? Choose BMC and benefit from:

- fast, convenient online submission

- thorough peer review by experienced researchers in your field

- rapid publication on acceptance

- support for research data, including large and complex data types

- gold Open Access which fosters wider collaboration and increased citations

- maximum visibility for your research: over $100 \mathrm{M}$ website views per year

At BMC, research is always in progress.

Learn more biomedcentral.com/submissions 